\title{
Global Warming and North Atlantic Fisheries: Attempting to Assess the Economic Impact
}

\author{
Ragnar Arnason. ${ }^{1}$
}

\begin{abstract}
Substantial global warming due to the accumulation of greenhouse gases in the Earth's atmosphere has been predicted for some time. These predictions are corroborated several sophisticated meteorological models. By the year 2100 these models predict global temperature increases of between 2 and $4.5^{\circ} \mathrm{C}$. It is clear that a temperature increase of this magnitude will have a major environmental impact, which might be most significant in Northern latitudes where temperature increases are predicted to be significantly higher than the global average. This paper examines the possible impact of global warming on the fish stocks in the North Atlantic and their contribution to the economy of Iceland, Greenland and Norway. It is found that the impact of global warming on the most valuable fish stocks is more likely to be positive than negative. Moreover, even if it turns out to be negative, the long-term impact on the Icelandic and Norwegian economies is unlikely to be significant. In the case of Greenland the economic impact is even more likely to be positive and might easily be quite significant.
\end{abstract}

\section{Ágrip}

Um alllanga hríð hefur pví verið spáð að uppsöfnun gróðurhúsalofttegunda í gufuhvolfi muni hækka hitaststig á jörðinni á komandi áratugum. Yfirgripsmikil veðurfarslíkön á síðari árum hafa styrkt pennan grun. Á grundvelli pessara líkana má ætla að um næstu aldamót hafi meðalhitastig á yfirborði jarðar hækkað um 2$4.5^{\circ} \mathrm{C}$. Ljóst er að hitnun af pessari stærðargráðu mun hafa veruleg umhverfisáhrif. Umhverfisáhrifin verða að öllum líkindum hvað mest á norðlægum breiddargráðum par sem hitnunin er talin verða talsvert yfir heimsmeðaltali. Í pessari grein er fjallað um möguleg áhrif hitnunar jarðar á fiskistofna í Norður-Atlantshafi og framlegð peirra til pjóðarbúskapar á Íslandi, Grænlandi og Noregi. Niðurstaðan er sú að líklegt sé að umrædd hitnun efli fremur en rýri verðmætustu fiskistofnana á pessum slóðum. Jafnvel pótt svo fari að petta fari á hinn veginn er talið ólíklegt að áhrif á íslenskan og norskan pjóðarbúskap verði umtalsverð. Hvað Grænland snertir eru áhrif af hitnun jarðar líkleg til að efla fiskistofna miklu meira en við Ísland og Noreg og áhrif peirrar aukningar á grænlenskan pjóðarbúskap gætu orðið veruleg.

JEL Classification: O13, Q20, Q22

Keywords: Global warming; gdp; fish stocks; fisheries

\footnotetext{
${ }^{1}$ Ragnar Arnason, Department of Economics, University of Iceland. E-mail: ragnara@hi.is. 


\section{Introduction ${ }^{2}$}

Meteorological models have predicted global warming for some time. Apart from natural variations - such as changes in the intensity of the sun's radiations, the earth's orbit around the sun, the earth's axial tilt and endogenous climatic cycles this warming is frequently, at least partly attributed to human activity in the form of greatly increased emission and concentration of so-called greenhouse cases. ${ }^{3}$ Indeed, an increase in the predicted concentration of greenhouse gases in the earth's atmosphere is the main exogenous variable driving the global warming predictions (Watson et al. 2001).

A major intergovernmental effort — the International Panel on Climate Change, (IPCC) established by the World Meteorological Organization (WMO) and the United Nations Environment Programme (UNEP) - has predicted an average global warming during the $21^{\text {st }}$ Century ranging from some $1-5^{\circ} \mathrm{C}$ (Watson et al. 2001). According to these predictions, the warming is predicted to be disproportionately high in Northern latitudes (Watson et al. 2001). Thus, in the Arctic as a whole the temperature might easily rise between 4 and $8^{\circ} \mathrm{C}$. In sub-Arctic areas, where most of the fisheries now take place its impact is more uncertain and, due to changes in the pattern of ocean currents, little temperature increase and even cooling may occur.

Obviously temperature increases of this magnitude will have a major impact on environmental conditions and, consequently, economic possibilities and activities in the North. This is now being investigated more closely by a special project called Arctic Climate Assessment (ACIA, http:/twww.acia.uaf.edu/) organized by the Arctic Council. Much of what is being said below is based on research done under the ACIA project.

ACIA is a circumpolar effort including the North Pacific and Arctic as well as the North Atlantic. In this paper we limit the discussion to North Atlantic, more precisely the Norway, Iceland-Greenland area. This leaves out the North-East, i.e. Newfoundland as well as the Pacific and Arctic areas. Most of the empirical analysis is based on Icelandic data, which are most complete.

The organization of this paper is broadly as follows. The next section briefly reviews the predictions on global warming especially as it pertains to northern waters. The following section, section 2, considers the likely impact of global warming on the commercial fish stocks and fisheries in the North Atlantic. In section 3 , we estimate a function relating changes in GDP to changes in fish production. In section 4 we apply this function to obtain estimates of the possible economic impact of changes in North Atlantic fish stocks due to global warming. Finally, in section 5, the main conclusions of the paper are summarized.

\section{Global warming}

Several large-scale meteorological models are currently predicting global temperatures in the future. These models are in broad agreement that there will be a

\footnotetext{
${ }^{2}$ The author would like to thank Ragnhildur Jónsdóttir for reading the article as well as two anonymous referees for valuable comments.

${ }_{3}^{3}$ The main greenhouse gases are carbon-oxide, $\mathrm{CO}_{2}$, Nitrous-oxides $\mathrm{N}_{2} \mathrm{O}$, methane, $\mathrm{CH}_{4}$ and sulphur-oxides, $\mathrm{SO}_{2}$ and $\mathrm{SO}_{4}$.
} 
general warming of the earth's atmosphere during the current century and beyond. However, the models differ significantly in their prediction of future temperature increases. Thus, by the year 2100 , the various models predict global temperature rises ranging from $2-4.5^{\circ} \mathrm{C}$. Taking into account the confidence intervals presented by the model builders, the likely range of temperature increase is between 1.5 and $6^{\circ} \mathrm{C}$ for the world as a whole. These predictions are illustrated in the graph in Figure 1 lifted from the IPCC home page (IPCC 2003).

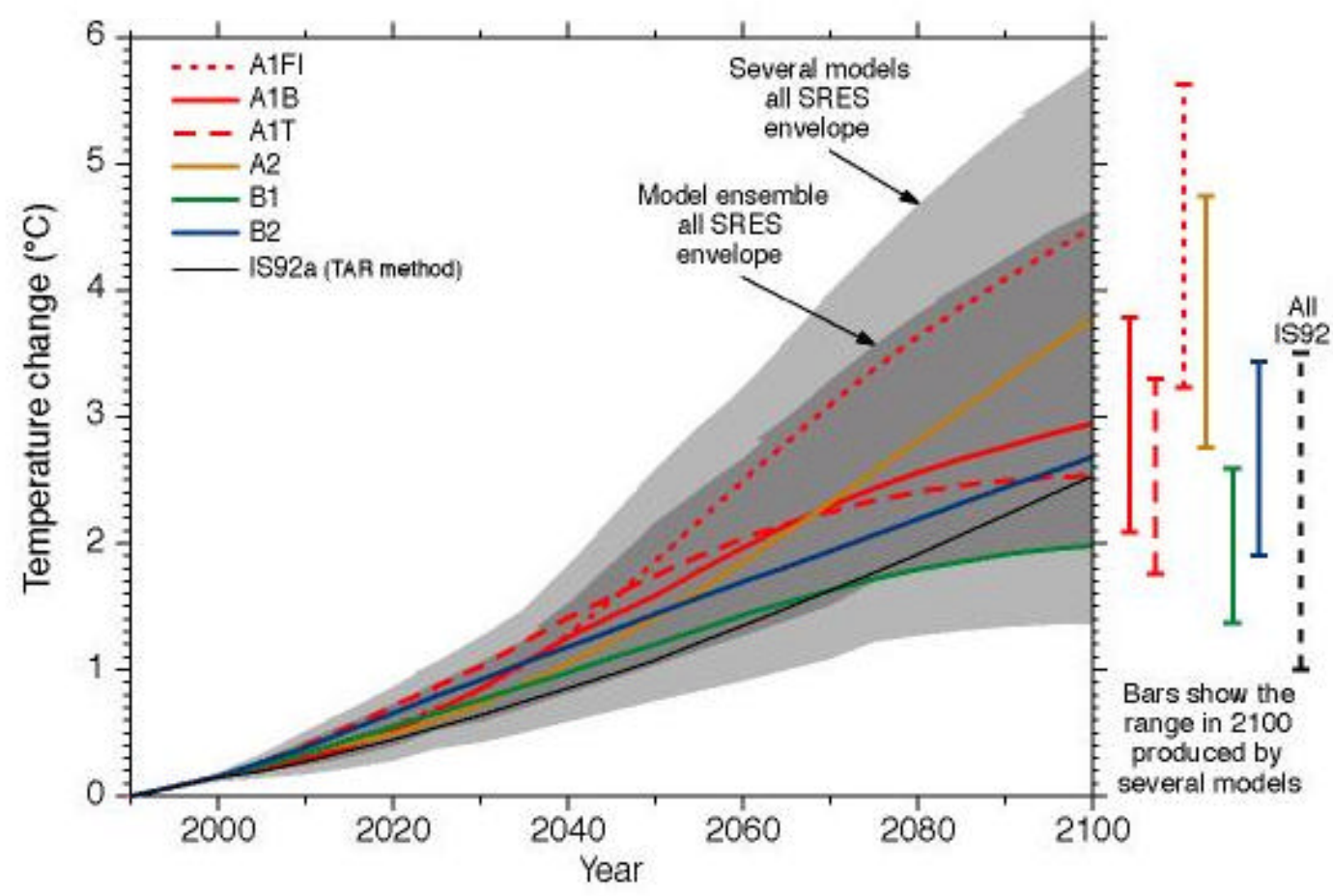

Figure 1. Predicted temperature increases (Source IPPC 2003).

So far observed rises in global temperatures have been in fair conformance with these predictions. It should be noted, however, that the number of predicted years is so far very small. Moreover, the predicted years of rapid rises in temperatures (see Figure 1) are yet to arrive. Therefore, these predictions should, as yet, be regarded as unverified by experience.

More importantly, it should be realized that all these meteorological models are driven by the exponentially rising accumulation of greenhouse gases in the earth's atmosphere. At the same time global temperatures have been rising. Thus, almost inevitably, a statistical approach will tend to identify a relationship between the accumulation of greenhouse gases and temperatures, even when none exists and the recent increase in global temperature is caused by other factors such as increased intensity of the sun's radiation. This is pointed out here in order to draw the reader's attention to the fact that due to possible model misspecification of various kinds, the predictions by these models of significant global warming are neither statistically not scientifically robust and, hence, subject to great uncertainty. At least the true confidence intervals for the temperature rise predictions are probably considerably wider than those illustrated in Figure 1, especially in a downward direction. 
The global warming models generally predict that the temperature rises in the Arctic will substantially exceed the global rise. This applies especially in the high Arctic where the ice cover is expected to diminish substantially with the effect that the surface absorption of solar radiation will greatly increase. Further to the south, partly because of the effects of melting ice and possible changes in ocean currents, the situation is much less clear. In many of the sub-Arctic ocean areas, it may be the case that ocean temperature will rise little or not at all. The following figure gives the predicted temperature rises for the various Arctic and sub-Arctic ocean regions.

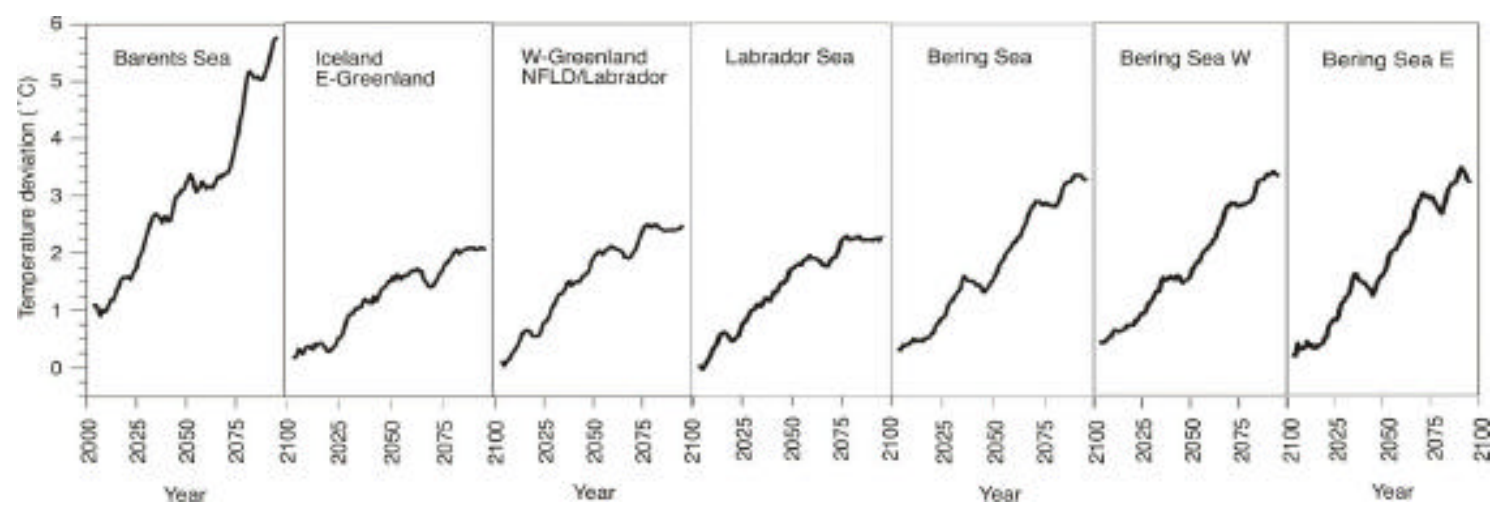

Figure 2. Average predicted temperature rises in northern waters (Source: ACIA working document).

As illustrated in Figure 2, the variability in predicted temperature increases from one region to another is quite substantial. The highest temperature rises are expected to occur in the Barents Sea, close to $6^{\circ} \mathrm{C}$ by 2100 . Note that these predictions are basically averages of several models. Some predictions are even higher. The predicted temperature increases in the Bering Sea are substantially less or $4^{\circ} \mathrm{C}$ by the year 2100. In the Iceland - Greenland area, the predicted temperature increases by the end of this century are only $2-3^{\circ} \mathrm{C}$.

\section{Impact on Fisheries}

The impact of global warming on fish stocks and fisheries is hard to judge. There are several reasons for this: First, as discussed above, there is a great uncertainty regarding the extent and speed of global warming.

Second, there is even more uncertainty regarding the warming in the North Atlantic. This holds not the least for those areas of the North Atlantic where most fishing currently takes place. These areas are often cold water- warm water frontiers where thermoclines are steep. Not surprisingly, it is precisely in these areas where global warming predictions are most uncertain.

Third, fisheries depend very much on local conditions; up-welling, mixing of water masses, water salinity, currents, ice formation and melting and so on. Temperature is only one of the factors affecting fish stocks. On the other hand, changed temperature influences all these other hydrographical factors. What these effects will be, however, is very hard to predict.

Fourth, it is clear that global warming will alter the configuration of ocean currents and, consequently, also the most favourable regions for fishing. This effect can be small or large. Some hydrological models suggest that global warming will 
have a major impact on the world's ocean current systems ${ }^{4}$. If that is the case, then there would be a correspondingly major impact on fishing conditions in the North Atlantic.

Fifth, any changes in habitat conditions due to global warming will alter the conditions for the various species in the marine ecosystem in different ways. This will give rise to an almost certainly very complicated and possibly drawn-out process of species adjustments and readjustments. The outcome of that process for individual species is very hard to predict. It may for instance easily be the case that species that experience favourable environmental changes are reduced in stock size due to less supply of prey that is unfavourably affected by the environmental change.

It follows from this that there is great uncertainty about the impact of global warming on the commercial fish stocks and fisheries in the North Atlantic. In the ACIA working group on Arctic fisheries (ACIA 2003) it was recognized that there simply wasn't enough hydrographical, biological and ecosystem knowledge to translate predictions of global warming, uncertain as they are, into predictions for fish stocks and fisheries with a reasonable degree of confidence.

Nevertheless, faced with the need to make some sorts of predictions, the ACIA working group on Arctic fisheries came to the following general conclusions regarding the main commercial fish stocks of the North Atlantic.

A warming of the magnitude predicted is more likely than not to be beneficial to the fisheries of the North Atlantic

Important species that would probably benefit are: Cod, haddock, saithe, herring, blue whiting, several species of flatfish and crustaceans (Norway lobster).

Important species that would probably decline are: Shrimp, capelin, Greenland halibut and some species of flatfish.

To a certain extent, especially in the Barents Sea, ocean warming will induce a northward shift in the range of some species.

Less ice cover may offer more access to fish stocks.

The case of cod, the single most important commercial stock in the North Atlantic, is particularly interesting. Extensive areas of the North Atlantic are currently marginally habitable for cod due to low temperatures. This holds in particular for the Greenland area and to a lesser extent for the northern part of the Barents Sea. A slight warming would make these areas habitable again with the consequent expansion in the range of cod of a very substantial magnitude. For instance, during the warm period in the North Atlantic between 1930 and 1960, the range of cod in the IcelandGreenland ecosystem expanded greatly as illustrated in Figure 3. At the same time the Greenland based cod stock became quite large, yielding catches similar to the Icelandic cod stock. The relationship between cod catches off Greenland and temperature changes in the $20^{\text {th }}$ Century is illustrated in Figure 4.

\footnotetext{
${ }^{4}$ Possibly weakening the Gulf-current substantially.
} 


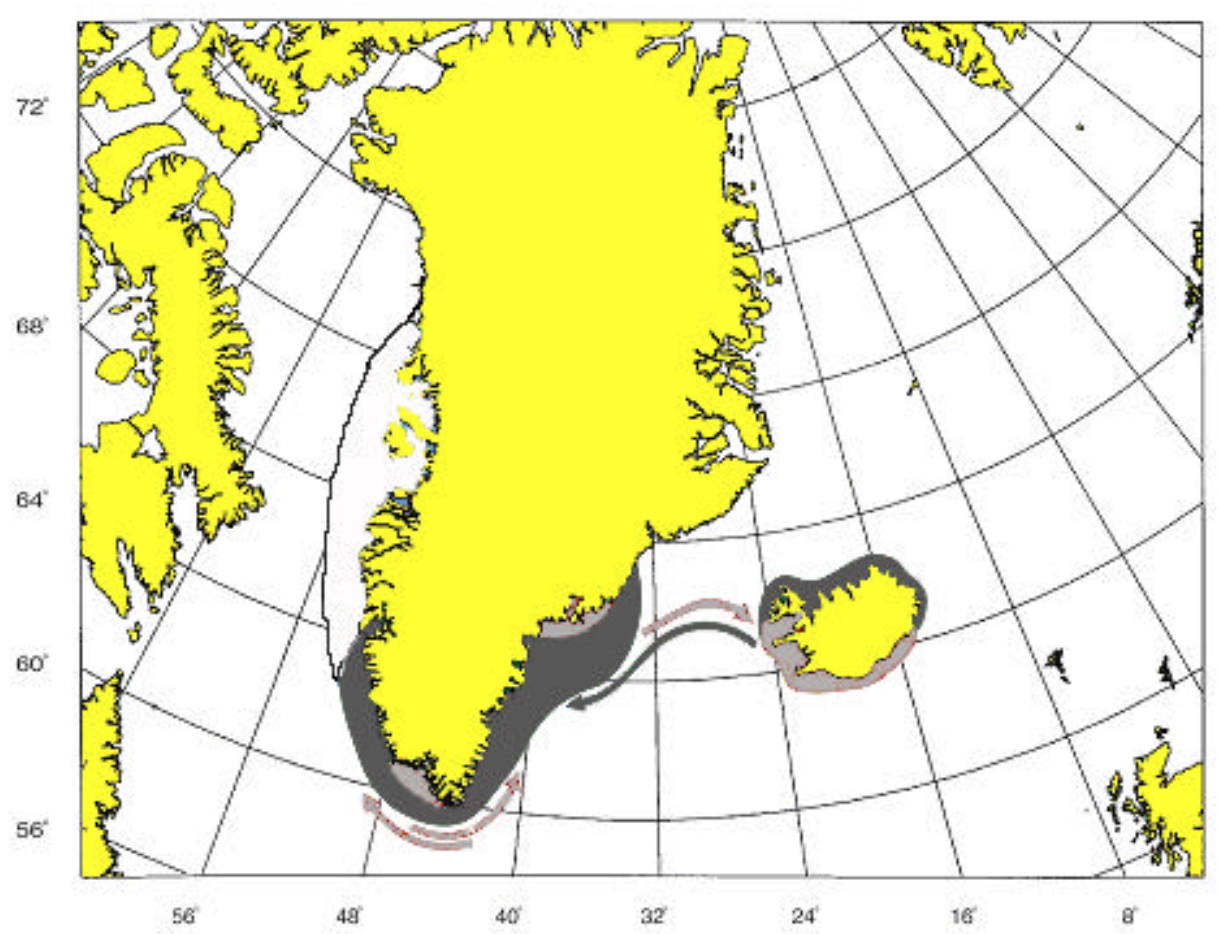

Figure 3. Expansion in the range of cod in the Iceland-Greenland ecosystem in the 1920s and 1930s (Dark grey colour indicates larval drift and juvenile grounds, light grey colour spawning areas).
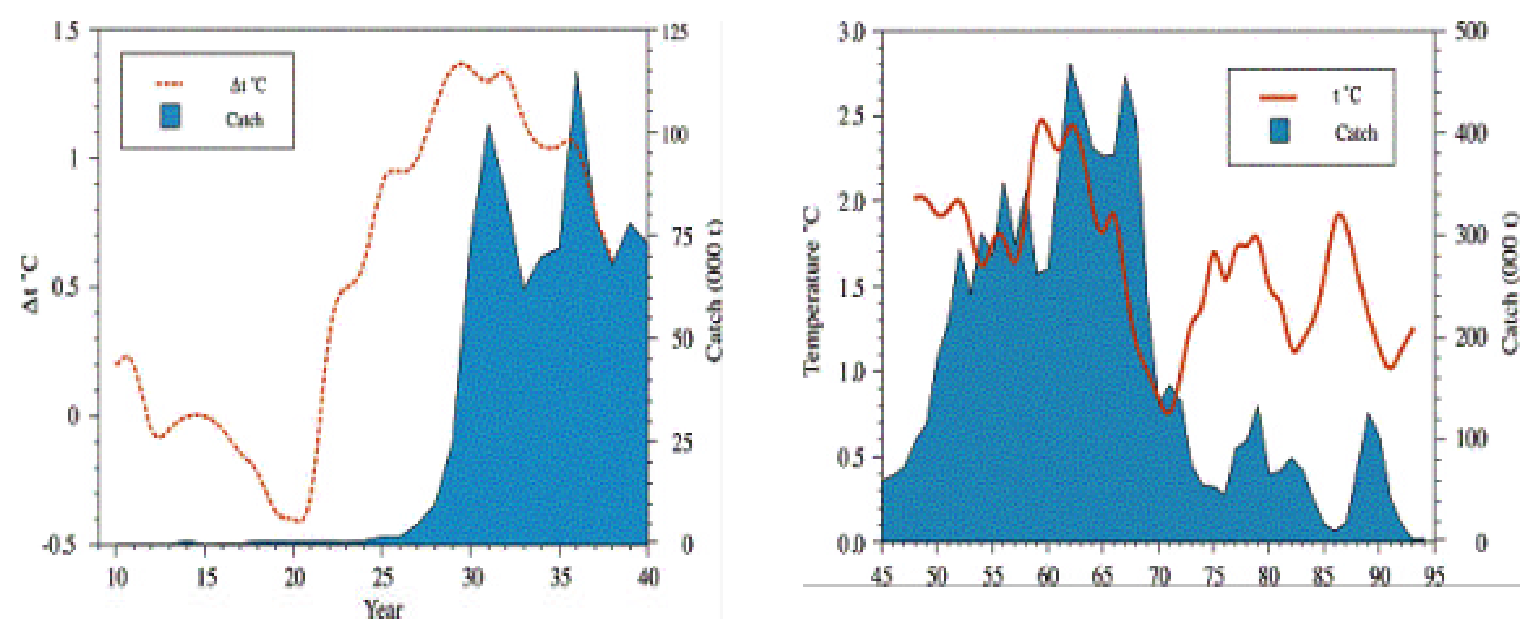

Figure 4. Cod at Greenland: Temperature and catch.

Thus, both biological arguments and historical experience suggest that some warming of ocean temperatures in the Greenland area will substantially improve the environmental conditions for cod and therefore, in all likelihood, lead to a greatly increased size of the cod stock in the in the Iceland-Greenland ecosystem. Ocean warming may affect other species differently. However, due to the high commercial value of cod, this positive effect is probably going to dominate any negative effects on say shrimp and capelin in the region. 


\section{Assessing the Economic Impact: Statistical Estimation}

We now turn our attention to the statistical estimation of the economic impact of a possible shift in the availability of fish to the fishing industries of the North Atlantic. The statistical estimation will be based on Icelandic data. However, due to the structural similarities of the economies in question, there are reasons to believe that the results for Iceland can be extrapolated to the economies of Greenland and North Norway as well.

\subsection{The economic importance of the fishing industries: National accounts}

Fisheries constitute an activity of major economic importance in the North Atlantic. In Greenland, the fishing industry is the main source of non-government employment and local economic activity with fish and fish products constituting over $90 \%$ of the total Greenland export (ACIA 2003). In Greenland, a major part of the national income consists of financial transfers from Denmark. Taking this into account and interpolating from the more complete Icelandic statistics, it may well be that about $50 \%$ of the Greenland GDP is generated in the Fisheries sector. In Iceland, in spite of a considerable relative decline, the fishing industry still accounts for 8-9\% of employment, $10 \%$ of the GDP and over $40 \%$ of total export earnings. In Norway, the fishing industry does not amount to major part of the economy as a whole. However, in Northern Norway, i.e. the area to the North of Trondheim, the fishing industry pays a similarly major role in economic life as it does in Iceland and Greenland.

\subsection{General equilibrium considerations}

It is important to realize that the national accounts statistics may well understate the real contribution of the fishing industry to the economies in these three countries. There are two fundamental reasons for this. First there are a number of economic activities closely linked with the fishing industry but not part of it. These activities consist of the production of inputs to the fishing industry, the so-called backward linkages, and the various secondary uses of fish products, the so-called forward linkages (Arnason 1994). The backward linkages include activities such as ship building and maintenance, fishing gear production, the production of fishing industry equipment and machinery, the fish packaging industry, fisheries research, educations and so on. The forward linkages comprise the transport of fish products, the production of animal feed from fish products, the marketing of fish products, retailing of fish products, part of the restaurant industry and so on. According to Arnason 1994, these backward and forward linkages may easily add at least a quarter to the GDP contribution of the fishing industry.

The other reason why the national accounts may underestimate the true contribution of the fishing industry to the GDP is the role of the fishing industry as a disproportionately strong exchange earner. To the extent that the availability of foreign currency constrains economic output, the economic contribution of a disproportionately strong export earner may be greater than is apparent from the national accounts. While the size of this "multiplier effect" is not easy to measure, some studies suggest it may be of a significant magnitude (Arnason 1994, Agnarsson and Arnason 2003). If that is true, the total contribution of the fishing industry to the 
GDP might easily be much higher than the above direct estimates suggest, in the sense that removal of the fishing industry would, ceteris paribus, lead to this reduction in the GDP.

It is equally important to realize that there are economic reasons why a change in the conditions of the fishing industry due e.g. to global warming, might have a lesser economic impact than suggested by the direct contribution of the fishing industry to GDP. This holds especially in the long run. Most economies exhibit certain resilience to exogenous shocks. This means that the initial impact of such shocks is at least partly counteracted by labour and capital moving to the economic activity made comparatively more productive by the shock. For instance, a negative shock in the fishing industry would be to a certain extent offset by labour and capital moving from the fishing industry to alternative industries and vice versa. As a result, the long-term impact of such a shock may be much less than the initial impact. The extent to which this type of substitution happens depends on the availability of alternative industries. However, with increased labour mobility, communication technology and human capital this type of flexibility is probably significantly greater than in the past.

\subsection{Statistical estimation: Iceland}

For centuries, pasture farming and fishing were Iceland's most important economic activities. By the end of the 19th century, fishing overtook farming in terms of economic importance. In 1910 almost $25 \%$ of the working population was engaged in fishing and fish processing generating almost $80 \%$ of the country's merchandise exports $^{5}$ (Figure 5). Although the fraction of labour working in the fishing industry declined from this high in the following decades, the importance of fish products in the exports actually increased to between $90-95 \%$ during the middle of the century (Figure 5). Since then, both the share of fish products in merchandise exports and the fraction of the total labour force engaged in fishing has declined significantly (Figure $5)$.

\footnotetext{
${ }^{5}$ Note that merchandise exports do not represent total export earnings. Total export earnings include the exports of services in addition to merchandise exports. Over time the share of services in total export has been increasing. Currently the export of services represents about $1 \beta$ of total export earnings in Iceland.
} 


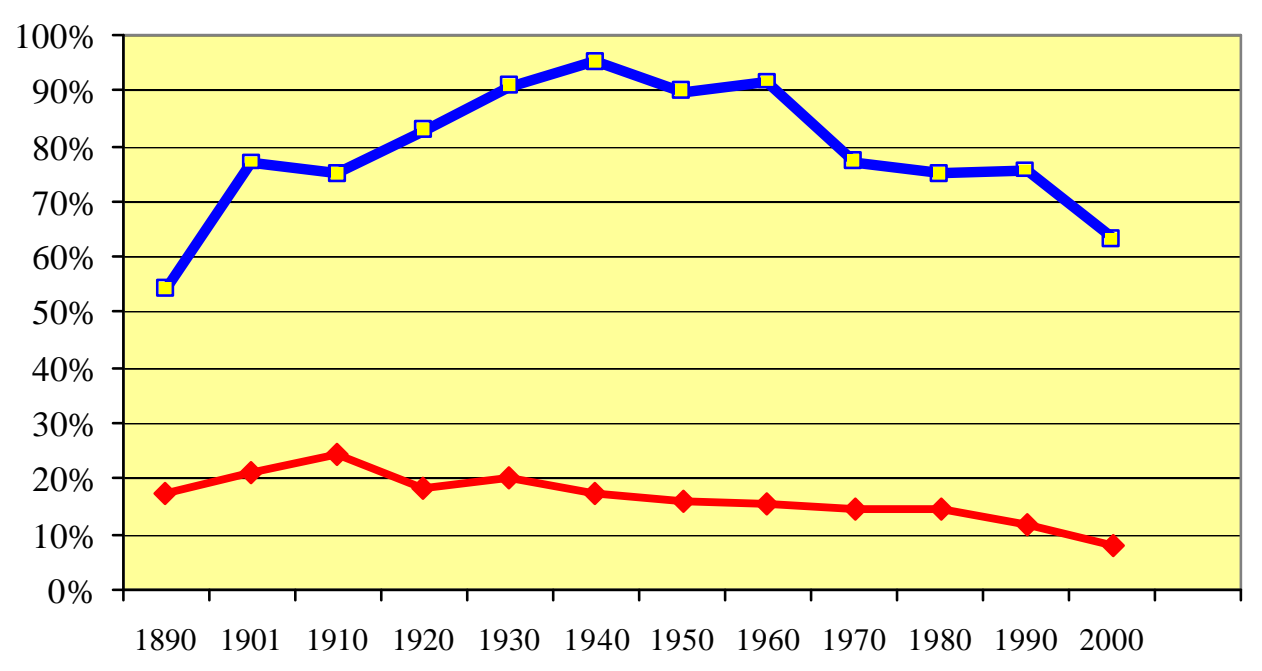

$\multimap$ Labour $\square$ Merchandise exports

Figure 5. Fishing labour and fish exports (as a percentage of total labour and merchandise exports) (Source: Statistics Iceland 1997).

National accounts estimates of the contribution of fishing industry (fishing and fish processing) to the gross domestic product (GDP) are available since 1980. According to these figures, the direct contribution of the fishing industry to the GDP is currently (2000) just over $11 \%$. In line with the trend in the fishing industry's labour and the export share, this represents a considerable decline compared to 1980 when the fishing industry contributed over $16 \%$ to the GPD (Figure 6).

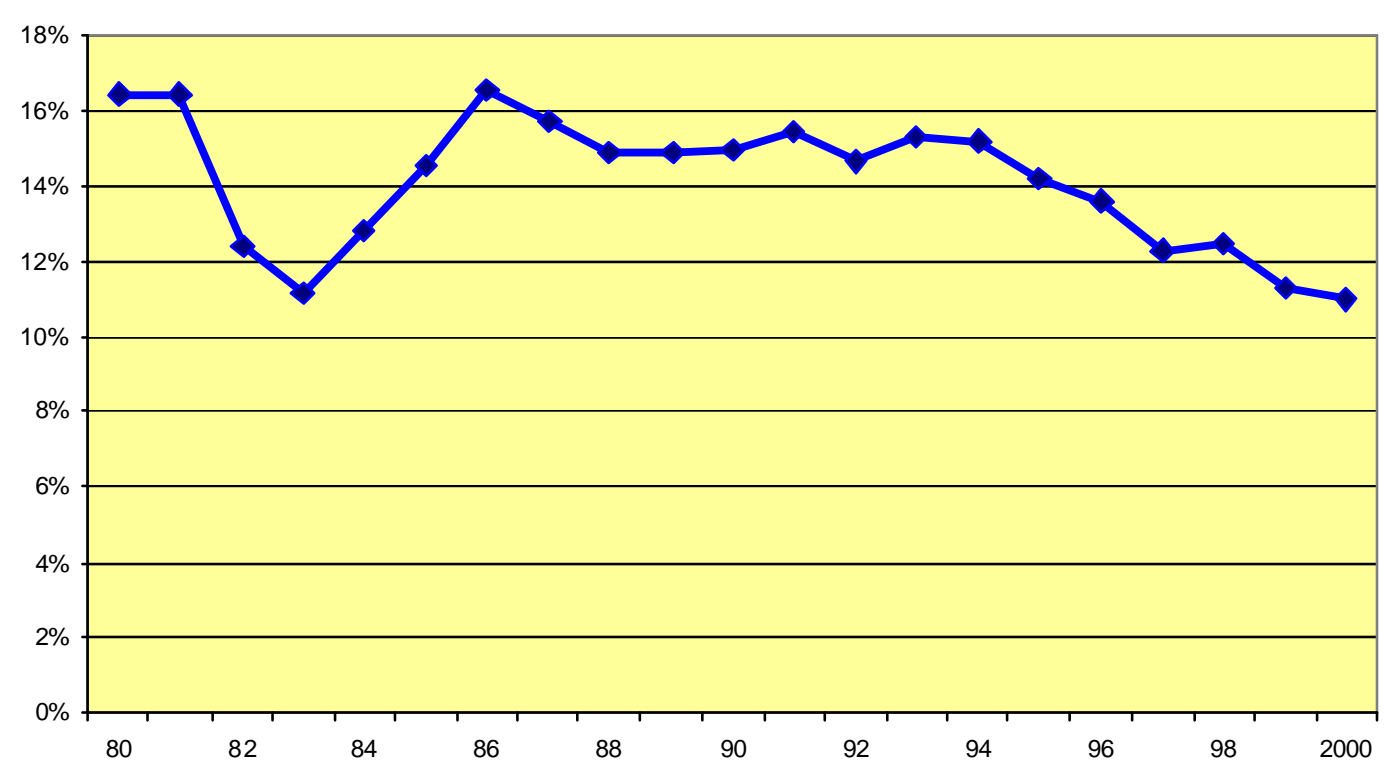

Figure 6. Contribution of the fishing industry to the GDP (Source: National Economic Institute 1995, 2002).

In fact, as suggested by Figures 5 and 6, the trend toward less economic dependence on fisheries has gained speed over time becoming particularly pronounced over the 
past 10-15 years. This declining trend in the relative importance of the fishing industry may be assumed to continue in the future.

In spite of the long-term decline in the macro-economic importance of the fishing industry, the Icelandic economy is still heavily dependent on fisheries. Thus, in the year 2000, the fishing industry accounted for some $8.2 \%$ of total labour, about $63 \%$ of merchandise exports and about $42 \%$ of total export earnings. In the same year the fishing industry contributed about $11 \%$ to the GDP.

The neoclassical theory of economic growth (see e.g. Solow 1970) suggests that economic output can be explained by the usage of capital and labour and the level of technology and, consequently, economic growth by the increase in these factors and technical progress. In the case of the Icelandic fishing industry, however, it appears that the output of the fisheries sector - to a large extent exogenous to the economic relationships of the neoclassical theory - needs to be added as an explanatory variable to this process. ${ }^{6}$ More to the point, the following equation was found to provide a good explanation of economic growth in Iceland during the available data period 1963-1996.

$$
\Delta y_{t}=\sum_{i=0}^{3} a_{i} \cdot \Delta x_{t-i}+\sum_{i=0}^{3} b_{i} \cdot \Delta k_{t-i}+c \cdot \Delta l_{t}+d
$$

where $\Delta y_{t}$ is the one-year percentage change in GDP, i.e. economic growth, $\Delta x_{t}$ the one-year percentage change in fishing industry output, $\Delta k_{t}$ the one-year percentage change in capital and $\Delta l_{t}$ the one year percentage change in labour. The $a_{i} \mathrm{~s}, b_{i} \mathrm{~s} c$ and $d$ are parameters. So, the equation as a whole explains percentage economic growth in Iceland in terms of a 3 year distributed lags of percentage changes in fishing industry output and capital, the percentage change in the current usage of labour and autonomous growth, $d$. This equation, estimated by ordinary least squares, gives a good fit to the data (Figure 7). Moreover its statistical properties appear reasonable ${ }^{8}$. The total impact of the three explanatory variables on GDP is provided in Table 1. The autonomous growth term, $d$, turned out to be insignificant.

\footnotetext{
${ }^{6}$ A likelihood ratio test on restricting the coefficients of fishing sector production to zero yielded a $\chi^{2}(4)=45.2$ which resoundingly rejects the restrictions. A Granger causality test based on vector autoregressive processes and co-integration analysis (Agnarsson and Arnason 2003) also strongly suggested that fish exports cause GDP maritime and not vice versa.

7 The multiple correlation coefficient is $\mathrm{R}^{2}=0.93$.

8 The usual diagnostic tests of residual independence and normality yielded tolerable results. Student $t$ and likelihood ratio tests of estimated coefficients suggested significance from zero in all cases except the intercept and so on. Further information on the estimation results are provided in the Appendix.
} 


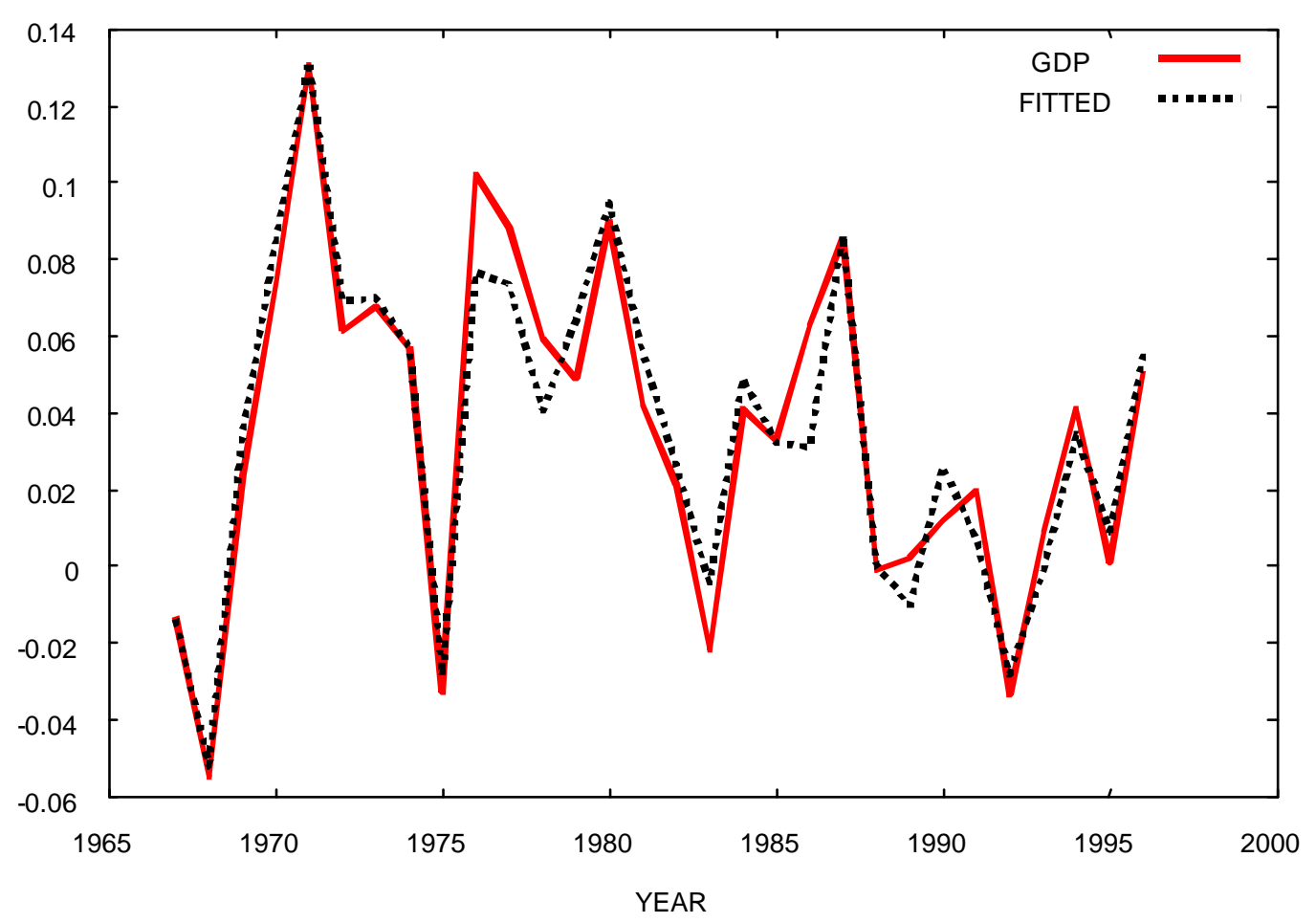

Figure 7. GDP growth in Iceland: Actual and fitted values

Table 1. The estimated total impact of changes in fish production, capital and labour on GDP growth in Iceland.

\begin{tabular}{rcc}
\hline Explanatory Variable & $\begin{array}{c}\text { Estimated } \\
\text { total impact }\end{array}$ & $\begin{array}{c}\text { Mean lag } \\
\text { (years) }\end{array}$ \\
\hline Fish exports, $\Delta x$ & 0.42 & 1.5 \\
Capital, $\Delta k$ & 0.21 & 2.4 \\
Labour, $\Delta l$ & 0.51 & 0 \\
\hline
\end{tabular}

According to the results presented in Table 1 a $1 \%$ change in the value of fishing industry production in Iceland will ultimately lead to a $43 \%$ increase in GDP. ${ }^{9}$ The GDP impact emerges gradually over a period of 3 years with about half of the impact apparent 1.5 years after the initial increase in fish production.

Thus we are faced with widely different estimates of the contribution of the fishing industry to the Icelandic GDP. On the one hand, the national accounts estimate the direct contribution of the fishing industry to the GDP to be some $11 \%$. Including immediate forward and backward linkages, this contribution could increase $14 \%$. On the other hand, the overall "portmanteau" estimates comprising the macro-economic multiplier effects discussed above, indicate a total GDP impact of the fishing industry of possibly over $40 \%$. Being all-inclusive, there are grounds to believe that the last estimate may be most sound.

\footnotetext{
9 The $95 \%$ confidence interval around this estimate is $\pm 11.3 \%$.
} 
Deeper economic analysis suggests, however, that both types of estimates, the national accounts-based one and the all-inclusive multiplier one, may suffer from a built-in overestimate of the long-term impact of the fishing industry on the GDP. The fundamental argument is in terms of substitution in production. If the fishing industry were to be permanently reduced, a readjustment would take place in the production sector. Labour and subsequently capital would move away from the fishing sector to other production alternatives. This adjustment would not be easy and initial productivity in new or newly expanded areas of production would initially be less, perhaps much less, than in the fisheries sector. Moreover, the extent and length of the adjustment process would depend on the macro-economic policies adopted. Nevertheless, in due course, perhaps decades later, the adjustment process would be complete and new industries would have replaced the fishing industry. The long-term importance of the fishing industry would be the difference between the old GDP, before the reduction in the fishing industry, and the new equilibrium one. Although, this difference will vary according to local and national conditions, it would normally be considerably less than the initial impact estimated by the traditional methods discussed above. In a reasonably advanced and globally integrated market economy, such as Iceland, it would be much less.

For these reasons, it seems reasonable to add a corrective term to the estimated equation (1) to reflect the long-term substitution in production that would occur if there was a long-lasting shift in fish stock availability, well in excess of the ones that have been experienced in the recent past. With these modifications equation (1) becomes:

$$
\Delta y_{t}=\sum_{i=0}^{3} a_{i} \cdot \Delta x_{t-i}+\sum_{i=0}^{3} b_{i} \cdot \Delta k_{t-i}+c \cdot \Delta l_{t}-\sum_{i=4}^{19} 0.02 \cdot \Delta x_{t-i}
$$

where the last term of equation (2), $-\sum_{i=4}^{19} 0.02 \cdot \Delta x_{t-i}$, represents a "guesstimate" of the long term counteracting economic adjustments. With this term added, the ultimate impact of a $1 \%$ reduction in fish production is about $0.1 \%$ reduction in the GDP. ${ }^{10}$

\section{Economic Impacts of Global Warming: Possible Scenarios}

From an economic point of view, climate change may impact fisheries in at least two different ways. First by altering the availability of fish to the fishermen. Second by changing the prices of fish products and fisheries inputs. The first impact is of primarily of a marine biological and ecological nature. The second is of an economic nature and must be investigated by the application of general equilibrium theory. Although both classes of impacts may be initiated by climate change, the first is a much more direct consequence of climate change than the second. The second is primarily a consequence of changed production conditions, often referred to by economists as a "supply shock", including but not limited to change in fish availability. It is generally promulgated by adjustments and readjustments

\footnotetext{
${ }^{10}$ It should be noted that this long-term adjustment term presupposes that economic conditions outside of the fishing sector remain largely as before. This implies e.g. that global warming does not adversely affect other economic conditions.
} 
throughout the economic system in very much the same way as exogenous impacts are promulgated through the ecosystem.

In this section we will calculate estimates of the possible GDP impact of changed fish stock availability as a result of climate change. These calculations are based on two key premises; (i) the impact of future climate change on the value of fish production in Iceland and (ii) the estimated relationship between economic growth and the value of fish production as discussed above (see Agnarsson and Arnason 2003). Both of these premises, not least the impact of climate change on the value of fish production, are highly uncertain. Therefore, the following calculations should not be regarded as predictions. They are merely intended to serve as indications of the likely magnitudes of the GDP impact in Iceland stemming from a certain stated premises regarding changes in fish stock availability.

\subsection{Scenarios}

Now, the available predictions suggest that the global warming during the next 50100 years is first of all not going to have a great impact on fish stock availability in Icelandic waters. Second, it is more likely to benefit the most valuable fish stocks rather than the reverse. These expectations, however, are highly uncertain as already mentioned. Therefore, in this section, we will proceed on the basis of three examples or scenarios.

In the first scenario we will assume a gradual increase in fish stock availability of $20 \%$ over a period of 50 years. This corresponds to a $0.4 \%$ increase in the value of fish production annually. We refer to this as the optimistic scenario. In the second scenario we will assume a gradual reduction in fish stock availability of $10 \%$ over 50 years. This corresponds to an annual reduction in the value of fish production by some $0.2 \%$. We refer to this as the pessimistic scenario. In the third scenario we assume a $25 \%$ reduction in fish stock availability occurring over a relatively short period of 5 years. This would correspond to a collapse in the stock size of a major or a group of important commercial species. Indeed, there are some biological and ecological grounds to believe that the response of fish stocks to climatic change may indeed be sudden and discontinuous rather than gradual. Due to the magnitude and suddenness of this reduction we refer to it as the dramatic case.

Hopefully these scenarios will serve to illustrate the likely range of the economic impacts of global warming around Iceland. [Needless to say, other, better-founded, examples can be calculated].

\subsection{The optimistic scenario}

In the optimistic case, fish stock availability is assumed to increase in equal steps by $20 \%$ over the next 50 years. The time profile of the impact of this on GDP relative to a benchmark GDP of unity is illustrated in Figure 8. 


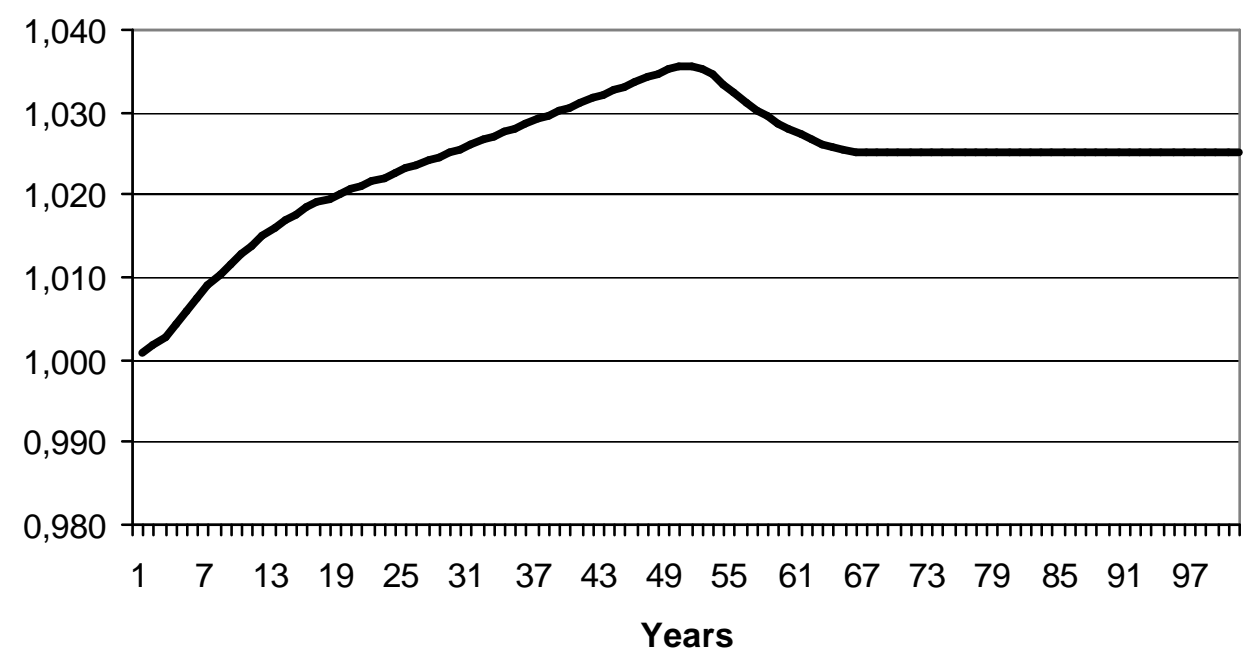

Figure 8. Impact of a $20 \%$ increase in fish production on GDP (Initial GDP=1.0. Annual increase in fish production $=0.4 \%$ ).

Perhaps the most noteworthy result illustrated in Figure 8 is that this; quite considerable increase in fish stock availability only has a relatively minor impact on GDP. The maximum impact occurs in year 50, when increased fish stock availability has fully materialized. At this point the GDP has increased (compared to the initial level) by less than $4 \%$. The long term impact, when economic adjustment processes have worked themselves out, is even less or some $2.5 \%$.

The annual impact of this increase in fish availability is more easily gauged by looking at annual economic growth rates. This is illustrated in Figure 9.

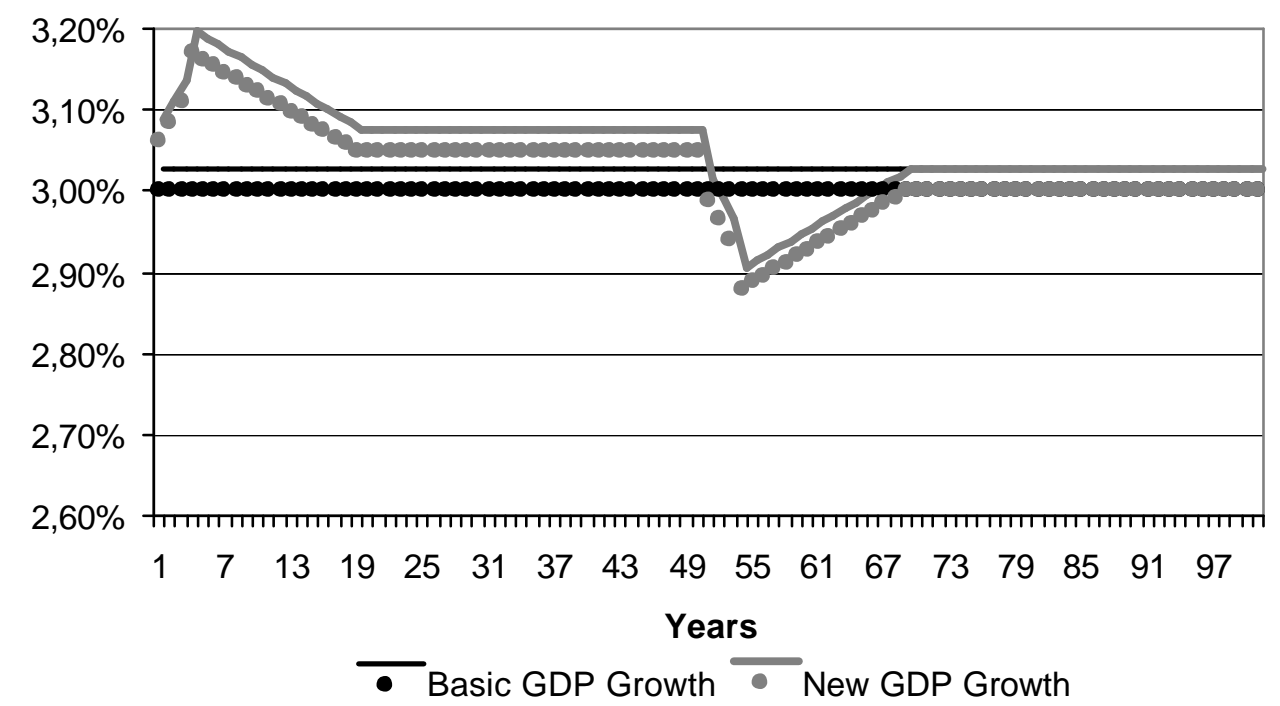

Figure 9. Impact of a \% increase in fish production on GDP growth (Basic (underlying) GDP growth rate $=3 \%$. Annual increase in fish production $=0.4 \%$ ).

As indicated in Figure 9, the largest increase in annual growth rates in any one-year is well under $0.2 \%$. This occurs soon after the increase in fish stock availability and, 
hence, fish production commences. For most of the period, however, the impact on annual economic growth rates is much less. In the years following the end of the increase in fish production, growth rates actually decline as production factors, moving to the fishing industry, reduce economic production elsewhere. It should be noted that all these deviations in annual GDP growth rates are well within GDP measurement errors. Long run GDP growth rates are, of course, unchanged.

The fundamental conclusions to be drawn from these calculations seem to be that a $20 \%$ increase in the output of the fishing industry equally spread over 50 years has a very small, indeed hardly noticeable, impact on the short run economic growth rates in Iceland as well as the long term GDP.

\subsection{The pessimistic scenario}

In the pessimistic case, fish stock availability is assumed to decrease in equal steps by $10 \%$ over the next 50 years. The time profile of the impact of this on GDP relative to a benchmark GDP of unity is illustrated in Figure 10.

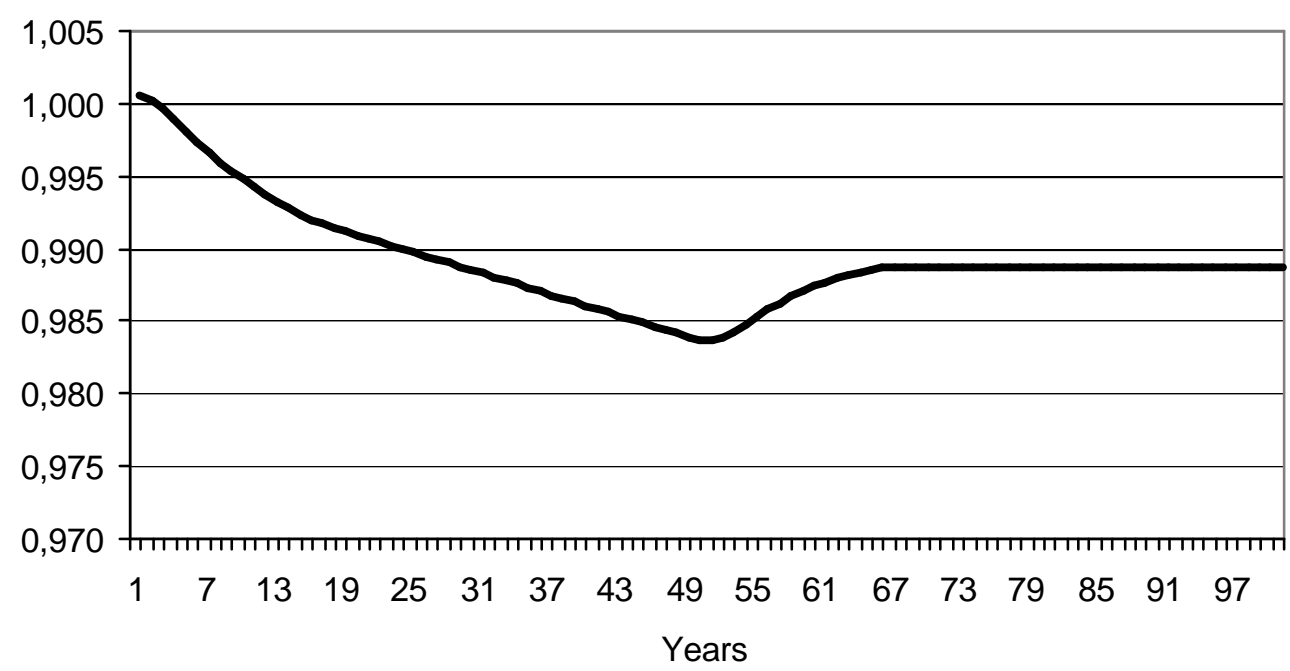

Figure 10. Impact of a $10 \%$ decrease in fish production over 50 years on GDP (Initial GDP=1.0. Annual increase in fish production $=0.4 \%$ ).

As in the optimistic case, the most striking result illustrated in Figure 10 is that this quite considerable decrease in fish stock availability has a relatively minor impact on long term GDP. The maximum impact occurs in year 50, when the GDP has been reduced by less than $2 \%$. The long-term impact, when economic adjustment processes have worked themselves out, is even less or just over $1 \%$.

The annual impact of this increase in fish availability economic growth rates is illustrated in Figure 11. 


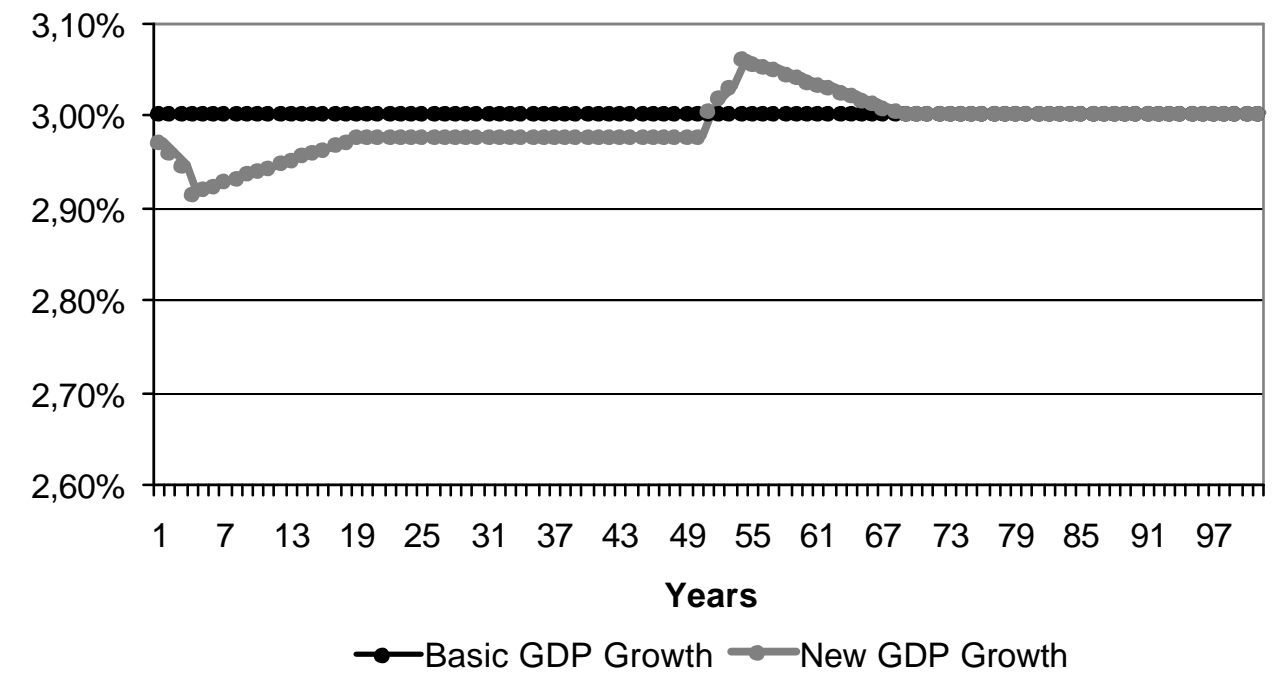

Figure 11. Impact of a $10 \%$ decrease in fish production on GDP growth (Basic (underlying) GDP growth rate $=3 \%$. Annual decrease in fish production $=0.2 \%$ ).

As indicated in Figure 11, the largest decrease in annual growth rates in any one year is well under $0.1 \%$. This occurs a few years after the decrease in fish stock availability begins. For most of the period, however, the impact on annual economic growth rates is much less. In the years following the end of the decrease in fish production, growth rates actually improve, as production factors, moving from the fishing industry, find productive employment elsewhere. The maximum annual decline is about $0.1 \%$. It should be noted that all these deviations in annual GDP growth rates are well within GDP measurement errors. Long run GDP growth rates are, of course, unchanged.

As in the optimistic case, the fundamental conclusions to be drawn from these calculations seem to be that a $10 \%$ decrease in the output of the fishing industry equally spread over 50 years hardly has a noticeable impact on the short run economic growth rates in Iceland as well as the long term GDP.

\subsection{The dramatic scenario}

The dramatic scenario assumes a fairly substantial drop in fish stock availability and, hence, fish production of $25 \%$ over the next 5 years. The resulting time profile of the impact of this on GDP relative to a benchmark GDP of unity is illustrated in Figure 12. 


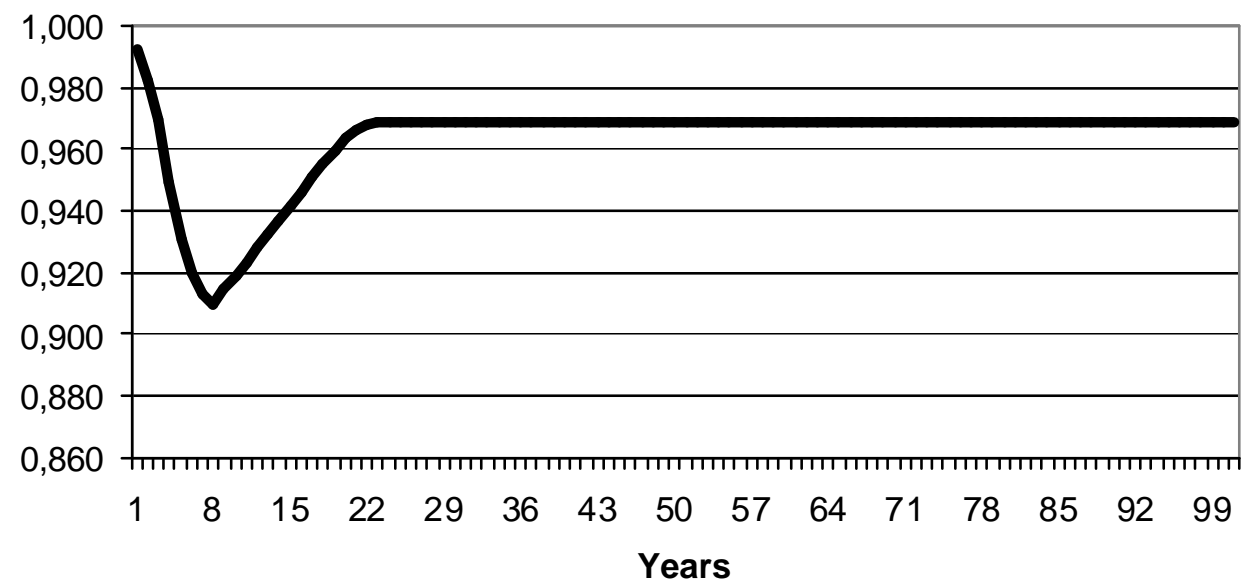

Figure 12. 25\% reduction in fish production over 5 years (Initial $\mathrm{GDP}=1.0$. Annual reduction in fish production $=5 \%$ ).

As illustrated in Figure 12, this sudden drop in fish stock production has a significant negative impact on GDP in the short run. At its lowest point, in year 8, GDP is reduced by over $9 \%$ compared to its initial level. The long term negative impact, however, when economic adjustment processes have worked themselves out, is only about $3 \%$ reduction in GDP.

The annual impact of this sudden reduction in fish production is illustrated in Figure 13.

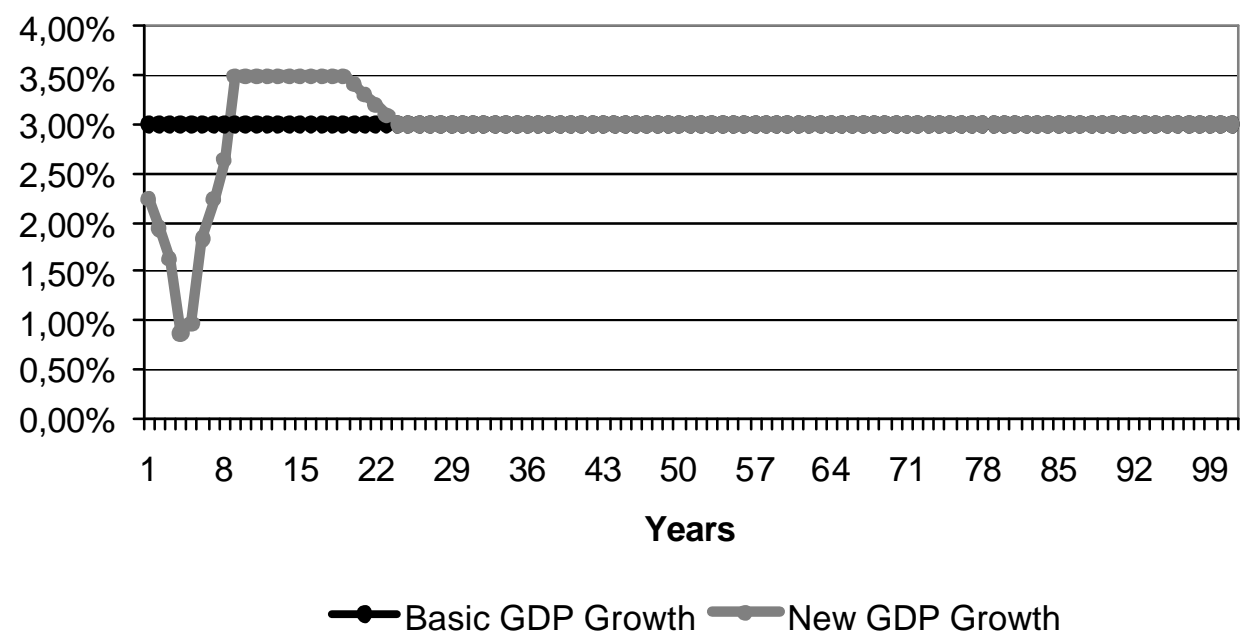

Figure 13. Impact of a $25 \%$ reduction in fish production over 5 years on GDP growth (Basic (underlying) GDP growth rate $=3 \%$. Annual reduction in fish production $=5 \%$ ).

As indicated in Figure 13, the decrease in annual growth rates for the first 7 years following the commencement of reduction in fish stock production are quite significant or $-1-2 \%$. The maximum decline occurs toward the end of the reduction process in year 4 and 5 . However, already, in year 9, four years after, the contraction ends, the deviation in annual GDP growth rates is reversed as production factors released from the fishing industry find productive employment elsewhere in the 
economy. This adjustment process is fully worked out in year 25, according to these calculations, when growth rates have fully reverted to the basic underlying economic growth level.

\subsection{Extrapolation to other North Atlantic economies}

The above calculations are for Iceland. However, there is good reason to believe that apart from scale similar relationships apply for Greenland and Norway.

In Greenland, the economic importance of the fishing industry is probably four times higher than in Iceland. Moreover, due to the importance of the cod stock, global warming is likely to have a substantially more positive effect than in Iceland. Finally, the flexibility, i.e. substitution possibilities, in the Greenland economy is probably significantly smaller than in the Icelandic economy. Thus, in Greenland, the optimistic scenario might easily generate $15-25 \%$ increase in GDP more than half of which might be permanent. The pessimistic scenario for Greenland would be similarly more dramatic. However, as already noted, the likelihood of adverse changes in Greenland waters is probably not very high at all.

In Norway regarded as a whole the fishing industry is much less important than in Iceland and the economy offers probably more alternative opportunities. Moreover, the likelihood of adverse changes is probably no greater than in Iceland. Hence, the effects of global warming on the Norwegian fisheries are bound to be even less economically noticeable than in Iceland. Focussing on Northern Norway, rather than Norway as a whole, the situation is probably quite similar to Iceland. However, the difference is that adverse changes are likely to meet with financial compensations in the form of transfers from other parts of the Norwegian economy.

\subsection{Impacts on fish markets}

Reduction or increases in fish production in the North Atlantic of the magnitude envisaged above will probably not have a significant impact on global fish markets. This holds especially if the changes are gradual. For certain species, however, especially demersals such as cod there might be a temporary noticeable effect. If there is an overall decline in the global supply of species of species that the North Atlantic nations currently exploit, the impact on marketing of these species is uncertain. Most likely the marketing of the species in reduced supply will become easier. Thus, prices will tend to rise counteracting the contraction in volume. However, it should be recognized that the marketing impact might actually be the opposite. For some species, a large and steady supply is required to maintain marketing channels. If this is threatened, these channels may close and alternative outlets have to be found.

\section{Conclusions}

The main conclusion to be drawn from the above is that the changes in fish stock availability that now seem most likely to be induced by global warming over the next 50-100 years are unlikely to have a significant long term impact on the Icelandic and Norwegian economies. In the case of Greenland, however, the impact may be much more noticeable and more long lasting.

If, on the other hand, global warming triggers sudden rather than gradual changes in fish stock availability, the short time impact on the Icelandic and 
Northern Norway GDPs, not to mention the Greenland one, and economic growth rates may be quite significant. The impact seems very unlikely to be dramatic (over $5 \%$ change in GDP between years), however.

More importantly, however, is that the impact of global warming on North Atlantic fisheries is more likely to be positive than negative. Most of the commercially important fish stocks, especially herring and cod, are much more likely to be favourably affected than the opposite. Hence, broadly speaking, global warming appears to be good news rather than bad for the North Atlantic fisheries at least.

Obviously, both short term and especially long run impacts may lead to social and political adjustments. These adjustments will have to be greater the larger and more permanent the impact is. In Iceland and Norway, these adjustments will almost certainly be very minor, except in certain particularly fish-dependent regions. In Greenland, the adjustments may easily have to be quite substantial.

\section{References}

ACIA (2003). Draft Report. Forthcoming.

ACIA (2003). http://www.acia.uaf.edu.

Agnarsson, S. \& Arnason, R. (2003). The Role of the Fishing Industry in the Icelandic Economy. An Historical Examination. Institute of Economic Studies. University of Iceland. (Forthcoming).

Arnason, R. (1994). The Icelandic Fisheries: The Evolution of a Fishing Industry. Oxford: Fishing News Books.

IPCC (2003). http://www.ipcc.ch.

Solow, R.M. (1970). Growth Theory: An Exposition. The Radcliffe lectures. Oxford: Claredon Press.

Watson, R.T. \& the Core Writing Team (Eds.) (2001). Climate Change 2001: Synthesis Report. Third Assessment Report of the Intergovernmental Panel on Climate Change. Cambridge: Cambridge University Press. 


\section{Appendix}

\section{Statistical estimation}

The following summarizes key results of the statistical estimation of equation (1)

Estimation equation: $\Delta y_{t}=\sum_{i=0}^{3} a_{i} \cdot \Delta x_{t-i}+\sum_{i=0}^{3} b_{i} \cdot \Delta k_{t-i}+c \cdot \Delta l_{t}+d$

$$
\begin{aligned}
& \Delta y_{t}=\ln \left(y_{t}-y_{t-1}\right) ; y_{t} \text { is GDP in year } t \\
& \Delta x_{t}=\ln \left(x_{t}-x_{t-1}\right) ; \text { is export value of fish products in year } t \\
& \Delta k_{t}=\ln \left(k_{t}-k_{t-1}\right) ; k_{t} \text { is total capital value in year } t
\end{aligned}
$$

Time series data: 1962-1996

Usable observations: 30

Estimation method: OLS

\begin{tabular}{|l|c|c|c|l|}
\hline Variable & $\begin{array}{l}\text { Aggregate } \\
\text { coefficients }\end{array}$ & t-statistic & Mean lag & $\begin{array}{l}\text { Exclusion } \\
\text { restrictions } \\
\text { Likelihood } \\
\text { ratio test }\end{array}$ \\
\hline Fish exports, $\Delta x$ & 0.42 & 7.4 & 1.5 & $\chi^{2}(4)=45.2$ \\
\hline Capital, $\Delta k$ & 0.21 & 1.2 & 2.4 & $\chi^{2}(4)=35.6$ \\
\hline Labour, $\Delta l$ & 0.51 & 3.2 & 0 & \\
\hline Constant & 0.002 & 0.2 & & \\
\hline
\end{tabular}

Diagnostic checks:

$\mathrm{R}^{2}=0.93$

DW-statistic $=1.81$

Jarque-Bera normality of residuals test: $\chi^{2}(2)=4$.6. Some evidence of skewness to the right. 